\title{
Utilization of Whey and Whey based Preparation in Processing and Development of Value Added Low-fat Meat Products
}

\author{
Kuleswan Pame ${ }^{1 *}$, B. Davuddin ${ }^{1}$, Sanjib Borah ${ }^{2}$, Jumi Dutta $^{3}$ and Pompi R. Boro ${ }^{3}$ \\ ${ }^{1}$ NDRI, Karnal-132041, Haryana, India \\ ${ }^{2}$ Lakhimpur College of Veterinary Science, AAU, Joyhing, North Lakhimpur (Assam), India \\ ${ }^{3}$ College of veterinary science, AAU, Khanapara (Assam), India \\ *Corresponding author
}

\section{A B S T R A C T}

\section{Keywords}

Whey protein, Low fat product and Fat replacer

\section{Article Info}

Accepted:

22 November 2020

Available Online:

10 December 2020
Research has proved the link of saturated fats to various chronic diseases, due to which there is an increasing trend on maintaining health and demand for food with lower fat content has been ever increasing by the modern society. This demand has necessitated developing value added products including meat products with low-fat content. Fat reduction can be achieved by using whey and whey based preparation. Whey protein has fat like properties and improves water binding capacity, increases juiciness and gives mouth feel of fat making it an excellent fat replacer in low fat meat products. In addition to their functional characteristics, they also contain readily digestible and bio-available essential amino acids, which provide a high nutritive value and plays a significant role in promotion of wellbeing. This paper reviews the various properties of whey and their use in the development of various value added meat products with lower fat contents.

\section{Introduction}

With liberalization of economic policies, increasing urbanization, influence of media and awareness on various health issues, there is an increasing trend on maintaining health and overall well-being. It has been seen that the demand for processed and quality meat product with lower fat content is ever increasing due various health issues and changing life styles (Sathu, 2014). This ever rising demand has necessitated developing nutritionally valued meat product without compromising the quality. Various non-meat ingredients have been used in formulation to enhance the quality of the product and economy of meat processors. Meat product added with non-meat ingredients pertain to the product with reduced fat, cholesterol, sodium, sugar or food products for vegetarians (Bolumar et al., 2015; GarciaSerna et al., 2014). Value addition by incorporation of novel ingredients includes: fat replacer/mimics, salt replacer, dietary fiber, natural antioxidants and non-meat proteins. Non-meat protein has been used in meat products to increase yield, reduce formulation costs or enhance specific functional properties (Keeton, 1994). Whey and whey preparations may serve as excellent 
substitutes. Besides consumers health, use of whey have many positive impact such as, impact on economy of the processor by reducing the cost of raw materials, thereby lowering the cost of production (Bozanic et al., 2014; Keaton, 1999; Singh \& Singh, 2012). Few decades ago production of huge quantities of whey was a serious problem by many dairy plants as it was not recycled to the extent it is done today. Whey was considered as by-product and are not properly utilised for value addition. It goes as waste along with sewage which posed a threat to the ecosystem due to its high organic compounds besides decrease the return from unit animal (Wesołowska-Trojanowska and Targonski, 2014). The use of whey and whey based product as substitute in value added meat product has been significantly increased due to changing attitudes of consumers, processors and food regulatory agencies. Whey enhances consumer appeal, improves nutritional value, and adds various functionality features to the product. Whey proteins are being widely used in processed meat products as binding, extending and texture modifying agents. Whey provides a high nutritive value due to the presence of readily digestible and bioavailable essential amino acids besides their functional characteristics. These proteins include $\beta$ lactoglobulin, $\alpha$-lactalbumin, lactoperoxidase, and lactoferrin which are the main source of whey health-promoting properties (Kumar et al., 2008). The following peptides were identified in the $\beta$-lactoglobulin sequences: $\beta$ lactorfin which influences the smooth muscles, $\quad \beta$-lactotensin which exhibits hypocholesterolemic and anti-stress activities, and in the $\alpha$-lactalbumin sequences $-\alpha$ lactorfin helps blood pressure reduction (Chatterton et al., 2006). Lactoferrin has a positive effect on the nervous system and is able to bind iron (Darewicz et al., 2014). Whey proteins can be used either as stand-alone proteins or as partial replacement of meat proteins. In restructured meat products such as nuggets, meat patties and restructured ham, whey proteins have been used to improve firmness, enhance slicing characteristics, reduce purge under vacuum packaging and improve binding between meat pieces and some of the important benefits of whey utilization is shown in Fig 1. Therefore, value addition of meat product by incorporation of whey protein concentrates and whey protein isolate has been seen as an opportunity to improve the image of meat and address consumer needs. Value addition with lower fat product constitutes a growing segment of the food processors with increasing demand. The recent trends in utilization of whey and whey preparation for development of functional and healthier meat products are discussed.

\section{Use of whey and whey preparation in meat products}

Meat and dairy products have been considered as the two main sources of protein for humans since time immemorial. Traditionally they have a common interest in maintaining a positive image for protein source of animal origin. Milk ingredients especially milk proteins can play an important role in the stabilization of meat products. The impact of whey protein and their substitutes on sensory, textural and other bio functional properties are given in Table 1.Meat processors use various whey and whey preparation such as sweet whey powder; 34$80 \%$ whey protein concentrates (WPC), more than $90 \%$ whey protein isolate (WPI), whey with reduced lactose content, demineralised whey, and lactosein various meat recipes (Keaton, 1999; Prabhu, 2006). They are mostly used in the preparation of comminuted meat products, such as: frankfurters, sausages, mortadellas, luncheon meat, or surimi (De Wit, 2001).WPC $80 \%$ has been used to replace egg white powder in preparation of 
minced fish products and a traditional Japanese product such as Surimi, due to its excellent gelling properties, the protein reinforces the gel, which is formed by the fish protein; it binds water and makes the product whiter and glossier (Jayaprakasha and Brueckner, 1999). The frying loss of smoked chicken sausage from broiler spent hens significantly reduced on addition of WPC (Rao et al,. 1999). Meatless patties containing $80 \%$ textured WPC with mushroom and vegetable flavour had similar acceptability as commercial soya patty (Taylor and Walsh, 2002). Whey protein may partially replace meat protein, as well as partially or completely substitute for soy protein and other binding agents, fillers, modified starch and hydrocolloids (Keaton, 1999; Prabhu, 2006; Youssef and Barbut, 2011). Incorporation of whey protein in various meat products enhances the water binding capacity that prevents the depletion of mass during thermal processing and storage of the product, increases juiciness and facilitates slicing property. It also increases the viscosity which improves the consumers' palatable impressions during consumption of the product which is directly related to the ability to bind water; high solubility in the range of $\mathrm{pH}$ from 2 to 10 , (ideal for use in injected products), while sodium caseinate is soluble at above $\mathrm{pH} 5.0$, and soy protein isolate only at $\mathrm{pH}$ above 5.5 ; the formation of stable emulsions, which is particularly important in the production of finely comminuted meat products, with poor quality raw materials; here, whey proteins may partially or completely replace other emulsifiers. Furthermore, the addition of whey proteins affects the taste and improves formation of gel (Keaton, 1999). Edible sausage casing can be prepared from whey protein. Moreover, liquid whey as such could be better option in improving the meat quality (Yetim et al., 2001). Mohapatra et al., (2013) reported that liquid whey incorporated as emulsion-based chevon nuggets showed better emulsion stability, higher fat and protein content (Table 1). They may also exhibit antioxidant activity in pork or lipid rich products (Prabhu, 2006). Mortadella incorporated with 34\% WPC and $90 \%$ whey protein isolates significantly increase the effectiveness (Keaton, 1999). Buffalo meat nuggets using low value meat like cheek meat, tongue, heart at $25 \%$ level with $7 \%$ maida flour, 3\% soya flour, $1 \%$ whole egg and 3\% liquid whey significantly increase emulsion stability, product yield and overall acceptability compared to nuggets without the liquid whey (Dushyanthan et al,. 2008).

\section{Whey protein as fat replacer/mimetic}

The problem of high fat intake has gained a considerable importance in the world due to the increased incidence of cardiovascular diseases and the link of fats to chronic disease is also well established. An important measure aimed at solving this problem is to increase the production of low-fat content food products. Consumer concerns about excess fat consumption of some types of lipids have led to the development of various value added meat product with lower fat content by the food processors. The demand for low-fat product with the same desirable attributes as the corresponding full-fat foods has created a distinct challenge to food manufacturers. Fat has functional properties that influence processing and the eating qualities of a food item, and these functions must be accounted for when lowering the fat in a product. Fat plays a major role in the appearance, mouth-feel, texture, juiciness, and flavour and storage stability of foods. Many of the physicochemical properties of meat and meat products can be altered by removal of fat. To compensate this, there is a need for fat replacement. A fat replacer is an ingredient that can be used to provide some or 
all of the functions of fat yielding fewer calories than fat. Fat replacers need to be able to replicate all or some of the functional properties of fat in a fat-modified food (Schwenk and Guthrie, 1997). The term fat replacer implies that a substance which has certain desirable physical or organoleptic attributes of fats which it replaces without any of the undesirable properties of fats (Hassel, 1993, Martin, 1999). These fat replacers can be lipid, protein or carbohydrate-based and can be used alone or in unique combinations. Fat replacers are generally categorized into two groups: fat substitutes and fat mimetic.

Fat substitutes are ingredients that resemble conventional fat and oils and can replace fat on a gram-for-gram basis. Because they are fat based, they are often stable at cooking and frying temperatures and provide all the functions of fat while yielding $<9 \mathrm{kcal} / \mathrm{g}$, which could be zero calories if none is absorbed. Fat mimetic are ingredient that mimic one or more of the sensory and physical functions of fat in the food. They are based on carbohydrate, protein or fat components used alone or in combination and provide from 0 to $9 \mathrm{kcal} / \mathrm{g}$. They provide lubricity, mouth feel, and other characteristics of fat by holding water. Fat mimetics are protein or carbohydrate ingredients which function by imitating the physical, textural, mouth feel and organoleptic properties of real fats (Owusu-apenten, 2005).

Whey proteinconcentrate has fat like properties and improves water binding capacity, increases juiciness and gives mouth feel of fat making it an excellent fat replacer in low fat meat products (Sun et al., 2018; Sroan and Kaur, 2003). In low fat meat products WPC 34, 50 and 80 enhances moisture content and fat entrapment, resulting in increased cooking yield, moisture retention and increase resistance to shrinkage, WPC at $4 \%$ level can be effectively used as a functional ingredients in low fat beef patties due to its heat gelation and emulsification properties. Sensory analysis indicates the $4 \%$ WPC is an optimal level with respect to juiciness and overall acceptability of the low fat beef patties, frankfurters, hot dogs and poultry products. The addition of $13-15 \%$ WPI in meat protein substitute product resulted in softer, lighter and less red product. WPI provided the best emulsifying and moisture retention. Increased protein content also significantly increased the hardness and springiness value of the product compared to product without addition of WPI (Mohamad et al., 2010). Formularies for a low fat ( $<2$ per cent) restructured turkey loaf with $0.2 \%$ carrageenan and $4 \%$ non-fat dry milk was developed, with good overall acceptability, cook yield, nutritional value and shelf life up to 40 and 60 days at 0 to $4{ }^{\circ} \mathrm{C}$ and $-20^{\circ} \mathrm{C}$, respectively under aerobic and vacuum packaging system (Naseera, 2007).

\section{Whey proteins as fat mimetic}

Fat mimetic are the most widely used ingredients for producing emulsion-based reduced-fat products. WPC are considered as fat mimetic and they have found extensive use in reduced-fat foods, either alone or in combination with other mimetic. The WPC used as fat mimetic are typically WPC34 and WPC80 respectively. Their use in low-fat foods offers many advantages. Their multifunctional characteristics provide several fat-like attributes. Their major functions are gelling, water binding, emulsification, viscosification and adhesion. Modifying processing conditions during the manufacture of WPCs can also selectively enhance specific functional aspects. A majority of fat mimetic applications for WPCs involve emulsification within applications such as salad dressings, mayonnaises, cream soups and sauces besides processed meats. 
Table.1 Effect of whey protein and its substitutes on meat quality

\begin{tabular}{|c|c|c|c|c|}
\hline $\begin{array}{l}\text { Ingredients } \\
\text { (combination) }\end{array}$ & Level of addition & Role & Product quality & Reference \\
\hline Fluid whey & $0-3 \%$ fluid whey & $\begin{array}{l}\text { Sensory and } \\
\text { textural } \\
\text { attributes }\end{array}$ & $\begin{array}{l}\text { In Frankfurters (combination of } \\
\text { lean beef and pork) preparation } \\
\text { fluid whey could replace ice } 100 \% \\
\text { with better overall acceptability and } \\
\text { improved texture. }\end{array}$ & Yetim et al. (2001) \\
\hline $\begin{array}{l}\text { Whey protein } \\
\text { fraction }\end{array}$ & $\begin{array}{llr}\begin{array}{l}\beta \text {-lactoglobulin } \\
\text { ascorbate }\end{array} & (3 \% \mathrm{w} / \mathrm{v}), \quad \text { sodium } \\
\text { tripolyphosphate } & (0.25 \%), & \text { sodium } \\
(0.5 \%) & & \text { spice } \operatorname{mix}\end{array}$ & $\begin{array}{l}\text { Sensory and } \\
\text { textural } \\
\text { attributes }\end{array}$ & $\begin{array}{l}\text { Frankfurters has shown improved } \\
\text { cooking loss and tenderness. }\end{array}$ & Hayes et al. (2005) \\
\hline $\begin{array}{l}\text { Whey protein } \\
\text { coating } \\
\text { solution }\end{array}$ & $\begin{array}{l}\text { Whey protein ( } 5 \% \text { aqueous solution } \\
\text { prepared by rennet coagulation), sorbitol } \\
(2.5 \% \text {, w/v), calcium chloride }(0.125 \% \\
\text { w/v) and carboxy methyl cellulose }(0.25 \% \\
\text { w/v) }\end{array}$ & $\begin{array}{l}\text { Anti-oxidant } \\
\text { activity }\end{array}$ & $\begin{array}{l}\text { Low fat sausages (pork ham) have } \\
\text { shown delayed lipid oxidation } \\
\text { compared to uncoated whey } \\
\text { solutions. }\end{array}$ & Shon, \& Chin (2008) \\
\hline Fluid whey & Replacement with ice flakes $0-100 \%$ & $\begin{array}{l}\text { Sensory and } \\
\text { textural } \\
\text { attributes }\end{array}$ & $\begin{array}{l}\text { Chevon nuggets produced by fluid } \\
\text { whey (emulsion based) has shown } \\
\text { higher fat, protein content and over } \\
\text { all acceptability. }\end{array}$ & Mohapatra et al. (2013) \\
\hline $\begin{array}{l}\text { Whey protein } \\
\text { isolate }(92 \% \\
\text { protein }) \\
\text { /nanocomposit } \\
\text { e films }\end{array}$ & $\begin{array}{l}\text { Whey protein isolate }(92 \% \text { protein, } 10 \% \\
\mathrm{w} / \mathrm{v}), \text { glycerol }(6 \% \mathrm{w} / \mathrm{w}), \text { cellulose } \\
\text { nanofibre }(7.5 \% \mathrm{w} / \mathrm{w}) \text { titanium oxide nano } \\
\text { particles }(1 \% \mathrm{w} / \mathrm{w}) \text {, rosemary essential oil } \\
(2 \% \mathrm{w} / \mathrm{v})\end{array}$ & $\begin{array}{l}\text { Anti-microbial } \\
\text { activity }\end{array}$ & $\begin{array}{l}\text { Lamb meat has shown better shelf } \\
\text { life upto } 15 \text { days packed under } \\
\text { these nano composite films whereas } \\
\text { control has shown only } 6 \text { days }\end{array}$ & Sani et al. (2017) \\
\hline $\begin{array}{l}\text { Whey protein } \\
\text { concentrate } \\
(81 \% \text { protein } \\
\text { wet basis })\end{array}$ & Curing solution with whey protein $(1-7 \%)$ & $\begin{array}{l}\text { Sensory and } \\
\text { textural } \\
\text { attributes }\end{array}$ & $\begin{array}{l}\text { Chicken breast meat has shown } \\
\text { improved sensory and textural } \\
\text { attributes but lowered the shelf life. }\end{array}$ & Ha et al. (2019) \\
\hline
\end{tabular}


Fig.1 Some of the important properties exhibited by whey and its substitutes in meat products

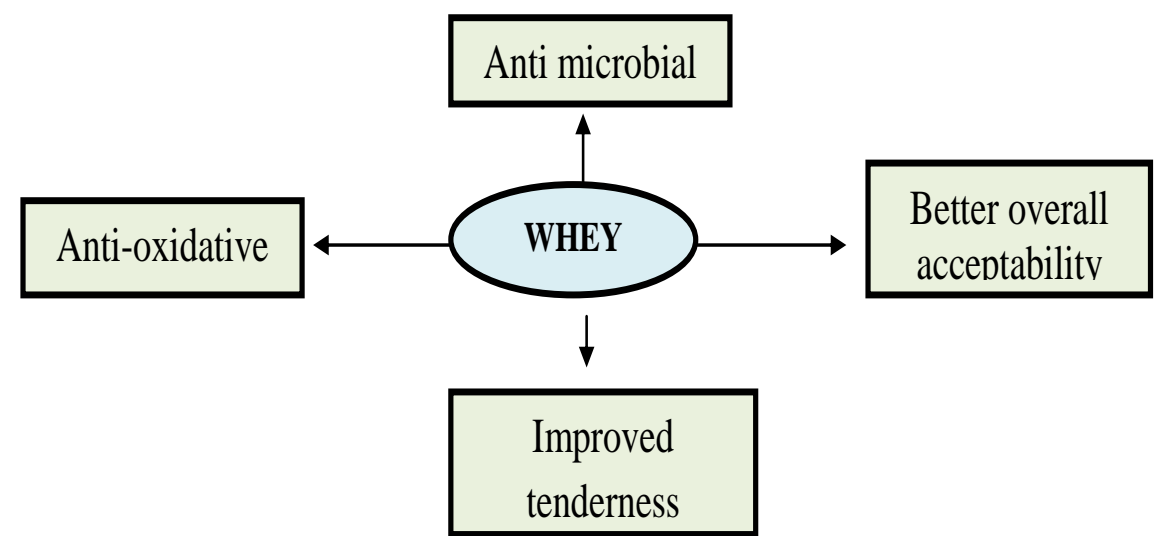

In addition, WPCs offer cost-efficiency benefits when replacing or extending egg whites, hydrocolloid gums, soy proteins and modified starches,

High Gelation: Studies have shown that highgelling WPCs, when combined with a gum and starch, yield a low-fat (3\%) pork sausage that has similar textural characteristics to a full-fat (20\%) control.

Cold Gelation: In meat applications using vacuum tumbling, cold-gelling WPCs can be added until the protein is in the meat, to be followed by the addition of salt to gel the WPC. Tests have shown that this method improves meat quality and yields.

Water Binding: Efficient water binding is an important function provided by WPCs in reduced-fat chopped meat and seafood products, providing improved texture and mouth feel. The retained water improves texture and reduces cost by replacing oil with water.

In conclusion the ever increasing consumer's awareness on consumption of low-fat diet and its health benefits is constantly growing. Thus, the challenge facing the food processing sector is to develop a variety of value added meat product with respect to lowfat content using whey and whey based preparation without compromising its taste. Various studies show the potential and practical importance of its use in meat products for value addition. Incorporation of whey in meat product may significantly improve meat product with respect to low-fat content, higher economic return and its effect on physicochemical properties. Value addition with whey can provide the satiety value and sensory properties of fat at a competitive price. Further studies need to be carried out in order to produce meat products incorporated with whey ingredients for value addition to meet better health benefits, as these products with lower fat content would form a strong market niche.

\section{References}

Bolumar, T., Toepfl, S. and Heinz,V. (2015). Fat reduction and replacement in drycured fermented sausage by using high pressure processing meat as fat replacer and olive oil. Pol. J. Food Nutr. Sci.,(65)175-182.

Bozanic, R., Barukcic, I., Jakopovic, K.L. and Tratnik, L. (2014).Possibilities of whey utilisation.Austin J. Nutri. Food Sci., 2, 1036. 
Chatterton, D.E.W., Smithers, G., Roupas, P. and Brodkorb, A. (2006). Bioactivity of $\beta$-lactoglobulin and $\alpha$-lactalbuminTechnological implications for processing. Int. Dairy J.,(16) 12291240.

Darewicz, M., Iwaniak, A. and Minkiewicz P. (2014). Biologically active peptides derived from milk proteins. Med. Wet. (70)348-352 (in Polish; English abstract).

De Wit J.N. (2001), Lecturer's handbook on whey and whey products. European Whey Products Association. Brussels, Belgium. Available at: [http://ewpa.euromilk.org/publications. html].

Dushyanthan. K., Narendra B. R. Vasanthi,C. and Venkataramanujam, V. (2008). Processing of buffalo meat nuggets utilizing different binders. Tamil Nadu J. Vety. \& Anim. Sci. 4 (2) 77-83.

Garcia-Serna, E., Martinez-Saez, N., Mesias, M., Morales, F.J. and del Castillo M.D. (2014) Use of coffee Silverskin and Stevia to improve the formulation of biscuits. Pol. J. Food Nutr. Sci. (64)243-251.

Ha, J. H., Lee, J. H., Lee, J. J., Choi, Y. I. and Lee, H. J. (2019). Effects of whey protein injection as a curing solution on chicken breast meat. Food science of animal resources, 39(3), 494.

Hassel, C.A. (1993). Nutritional implications of fat substitutes. Cereal Foods World, 38: 142144 .

Hayes, J. E., Desmond, E. M., Troy, D. J., Buckley, D. J. and Mehra, R. (2005).The effect of whey proteinenriched fractions on the physical and sensory properties of frankfurters. Meat Science, 71(2), 238-243.

Jayaprakasha, H. M. and Brueckner, $H$. (1999). Whey Protein concentrate: A potential functional ingredients for food industry. Journal of Food Science and
Technology. (36)189-204.

Keaton J. (1999). Whey protein and lactose products in processed meats (online). U.S. Dairy Export Council: Applications Monographs. Available at: [http://www.usdec.org/fi les/ pdfs/6meat.pdf].

Keeton, J.T. (1994). Low fat meat problems.Technological problems with processing. Meat Science, 36:261-271.

Kumar, R., Sangwan, R.B.and Mann, B. (2008). Separation and application of bioactive whey proteins. Technological Advances in the utilization of dairy by-products, 22nd Short Course Available at: [http://www.dairyprocessingcaft.com/w p-content/uploads/2012/05/Byproducts2008.pdf].

Martin, K. (1999). Replacing the fat. Food Engineering International, June, 57-60.

Mohamad K., Youssef and ShaiBarbut (2010).Effects of caseinate, whey and milk proteins on emulsified beef meat batters prepared with different protein levels. J. of muscle food. 21(4)

Mohapatra, S., Kandeepan, G., Mendiratta, S. K., Soni, B., Kumar, B., Vishnuraj, M. R. and Shukla, V. (2013).Effect of fluid whey incorporation on quality of chevon nuggets. Italian Journal of Food Science, 25(4), 379.

Nazeera, A.P. (2007). Quality and shelf life of low fat restructured turkey meat loaf. M.V.Sc. thesis, Kerala Agricultural University, Thrissur, Kerala, 78p.

Owusu-apenten, R. (2005). Introduction to Food Chemistry.CRC Press, Washington, D.C.

Prabhu, G. (2006). Whey proteins in processed meats. U.S. Dairy Export Council,

Rao, K. H., Rao, K. V. S. S., Singh, R. R. B., Anjaneyulu, A. S. R. and Yadav, P. L. (1999). Milk proteins as emulsion stabilizers in comminuted meat 
products. Indian Food Industry. (18)287-298.

Sani, M. A., Ehsani, A. and Hashemi, M. (2017). Whey protein isolate/cellulose nanofibre/TiO2 nanoparticle/rosemary essential oil nanocomposite film: Its effect on microbial and sensory quality of lamb meat and growth of common foodborne pathogenic bacteria during refrigeration. International journal of food microbiology, 251, 8-14.

Sathu, T. (2014). Development and evaluation of functional chicken nuggets. Doctor of Philosophy Thesis, Kerala Veterinary and Animal Sciences University, Pookode.46 p.

Schwenk, N.E. and Guthrie, J.F. (1997). Trends in marketing and usage of fatmodified foods implications for dietary status and nutrition promotion. Fam. Econ. Nutr.Rev. 10: 16-32.

Shon, J. and Chin, K. B. (2008). Effect of whey protein coating on quality attributes of low-fat, aerobically packaged sausage during refrigerated storage. Journal of food science, 73(6), C469-C475.

Singh, A.K. and Singh, K. (2012). Utilization of whey for the production of instant energy beverage by using response surface methodology.Advance J. Food Sci. Technol. (4)103-111.

Sroan, B. S. and Kaur, A. (2003). Succeeding fat: A profile of fat replacers in food
industry.Indian food industry. (22)4146.

Sun, C., Liu, R., Liang, B., Wu, T., Sui, W. and Zhang, M. (2018). Microparticulated whey protein-pectin complex: A texture-controllable gel for low-fat mayonnaise. Food Research Int., 108:151-160.

Taylor, B. J. and Walsh, M. K. (2002).Development and Sensory analysis of a textured whey protein meatless patty.Journal of Food Science. (64)1555-1558.

Wesołowska-Trojanowska, M. And Targoński, Z. (2014). The whey utilization in biotechnological processes. NaukiInżynierskie i Technologie, 1(12), 102-119 (in Polish; English abstract).

Yetim, H., Müller, W. D. and Eber, M. (2001).Using fluid whey in comminuted meat products: effects on technological, chemical and sensory properties of frankfurter-type sausages. Food Research International, 34(2-3), 97-101.

Youssef, M.K. and Barbut, S. (2011). Effects of two types of soy protein isolates, native and preheated whey protein isolates on emulsified meat batters prepared at different protein levels. Meat Sci. (87)54-60.

\section{How to cite this article:}

Kuleswan Pame, B. Davuddin, Sanjib Borah, Jumi Dutta and Pompi R. Boro. 2020. Utilization of Whey and Whey based Preparation in Processing and Development of Value Added Low-fat Meat Products. Int.J.Curr.Microbiol.App.Sci. 9(12): 3308-3315. doi: https://doi.org/10.20546/ijcmas.2020.912.394 